\title{
木造大スパン構造建築物における重量床衝撃音遮断性能に関する研究 床構造仕様別の床衝撃音遮断性能改善方法に関する実験的検討その 1 \\ A STUDY ON THE HEAVY FLOOR IMPACT SOUND INSULATION PERFORMANCE IN A WOODEN LONG-SPAN STRUCTURE BUILDING
}

An experimental study on improvement methods of floor impact sound insulation performance with floor structure specification Part 1

阪 本一生*, 井上勝夫**, 秋本 恭平***

Kazuki SAKAMOTO, Katsuo INOUE and Kyohei AKIMOTO

The purpose of this study is the improvement of the heavy floor impact sound insulation performance in a wooden building. The Experiment using real-scale long-span wooden construction with a large cross-section laminated lumber. We proposed a floor cross-section specifications of each heavy floor impact sound insulation performance rank from the result. The structure of the floor are two types, which is rigid structural system and vibration-proof structure system. This study supported the floor cross-section specification that allows up to heavy floor impact sound insulation performance L-55 was obtained. Therefore, it was found that it is possible to realize a performance comparable to $\mathrm{RC}$ construction in wooden construction.

Keywords : Wooden Construction, Long-Span, Heavy Floor Impact Sound, Sound Insulation Rank 木造, 大スパン，重量床衝撃音，遮音等級

\section{1. はじめに}

平成 12 年以降の改正建築基準法の施行による, 耐火建築物の木造 禁止の撤廃を契機に, 集成材・LVL・CLT 等の構造用部材の開発が進 むとともに，「燃えしろ設計」「燃えどまり設計」等の木造耐火建築 物の設計に関わる技術も進歩し，その設計基準等についてもまとめ ていく方向で検討が行われている。

また, 平成 22 年に「公共建築物等における木材の利用の促進に関 する法律」が成立, 施行された。この法律は, 国産木材の利用を促 進することが, 地球温暖化の防止・循環型社会の形成・自然共生社 会の醸成に貢献すること, 延いては森林の適正な整備・育成及び木 材の自給率の向上に寄与することを目的としている。然るに, 国は 率先して公共建築物への木材利用に取り組むとともに, 地方公共団 体や民間企業にも国の方針に即した木材利用の主体的な取り組みを 促し, 住宅などの一般建築物への波及を通して木材全体の需要拡大 を図っている。こうした状況を背景として, 林野庁の報告によると, 平成 26 年度に着工された公共建築物の木造率は $10 \%$ を超えたとさ れており，官民を問わず多くの大型木造建築物が計画され，施工さ れている。

一方，木質系構造は，一般的に低剛性・低質量であることから， $\mathrm{RC}$ 構造等他の構造に比べて音響性能上劣っていることは否めない。 なかでも, 重量床衝撃音遮断性能を従来工法によって向上させるこ
とは極めて難しい。このため, 日本建築学会の遮音性能基準 ${ }^{1)}$ でも, 木造集合住宅の重量床衝撃音の適用等級 3 級に, $\mathrm{RC}$ 構造等を対象に した L-60 よりも低い L-65 の性能を提示している。木造公共建築物 等に対しても, 全体的な性能の向上と技術開発の促進のためにも, 遮断性能基準の設定が必要であると考えられる。

木質系床構造の振動特性は非常に複雑であり，目標性能を簡易か つ経済的に達成寸るのはかなり困難な状況にある。また，木造は物 性の変化, 部材の接合方法の問題から実験的検討の必要性が伺える。 我々はこれまでに，木造床構造の重量床衝撃音低減方法の研究によ り，木造軸組構法（在来工法）に高剛性方式を採用し，L-55 の性能 を達成している ${ }^{2)}$ 。また，木質系共同住宅の設計指針1) へも各目標 性能に対する床構造仕様例として, これらの断面を掲載している。

また，田中らは，近年大規模な建物への採用が増加している CLT 工法 $^{3)}, 2 \times 4$ 工法 ${ }^{4)}$ といった仕様断面により L-65～60 の遮音性能 を達成しており, 大スパン木造建築の床構造仕様が幅広く確保され つつある。しかしながら, 公共建築物の木造化が促進される中で, L-55 以上の遮音性能の仕様例は僅かであり，床仕様の更なる拡張が 必要である。また，大スパン化に伴い高剛性方式の応用が可能で女 るか，実験を通して検証する必要もある。本報では，大断面集成材 を用いた木造大スパン構造建築物の実大実験を行い，その結果を踏 まえて重量床衝撃音遮断性能毎の床断面仕様の具体的な提案を目的

\footnotetext{
* 日本大学理工学部建築学科 助手 · 修士 (工学)

** 日本大学理工学部建築学科 教授. 工博

*** 元日本大学理工学部 大学院生
}

Research Assoc. of Architecture, College of Science and Technology, Nihon Univ., M. Eng. Prof., Dept. of Architecture, College of Science and Technology, Nihon Univ., Dr. Eng.

Former Grad. Student, Graduate Scool of Science and Technology, Nihon Univ. 
として, 高剛性構造方式床 4 種類, 防振構造方式床 1 種類について 報告する。

\section{2. 実験概要}

\section{1 床衝撃音の対策部位と方法}

図 1 に木造床における床衝撃音発生フローおよび対策部位と方法 を示す。床面に衝撃力が作用した際に生じる床構造振動から, 音響 放射により天井内空間に音圧が発生する。天井内空間の音圧は天井 面を加振し, 下室への放射音となる。また, 床構造の衝撃振動は, 下室の壁や床に伝搬し, 壁面・床面を振動させて音として下室に放 射される。下室においては, これらの放射音が合成され遮断性能を 決定することになる。

本報では，これらの床衝撃音発生系のうち，影響の大きい上階の 床構造, 下階の天井構造および下階の壁構造 ${ }^{5)}$ に着目した実験結果 を報告する。

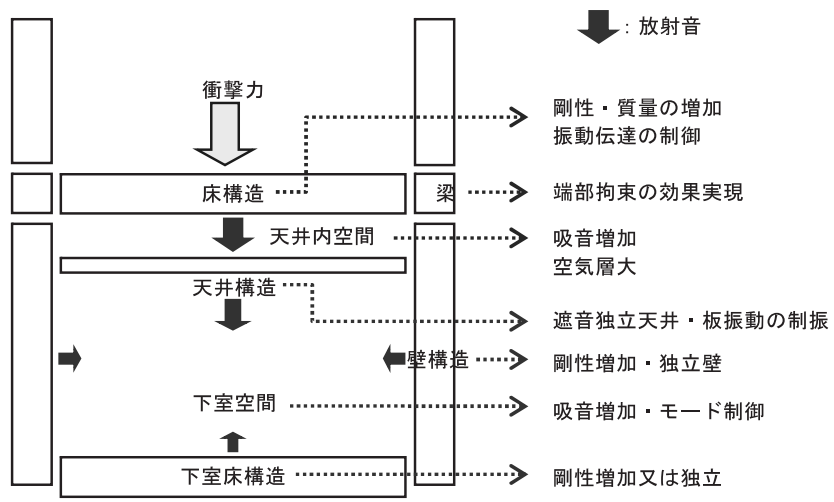

図 1 床衝撃音発生フローおよび対策部位と方法

\section{2 実大木造モデルの架構}

実物大の 2 階建て実験用木造建築モデルをスパン $6 \mathrm{~m} \times 6 \mathrm{~m}$ の両方向 ラーメン構造で施工した。架構には集成材を用いた柱 $(450 \times 450)$, 大梁 $(300 \times 930)$, 小梁 $(180 \times 600)$ および根太 $(105 \times 105)$ 等を使 用している。

天井構造としては, 床躯体構造と独立した木質複合梁（I 型ジョ イスト）を用いた独立遮音天井（標準仕様：強化石膏ボード $12.5 \mathrm{~mm}$

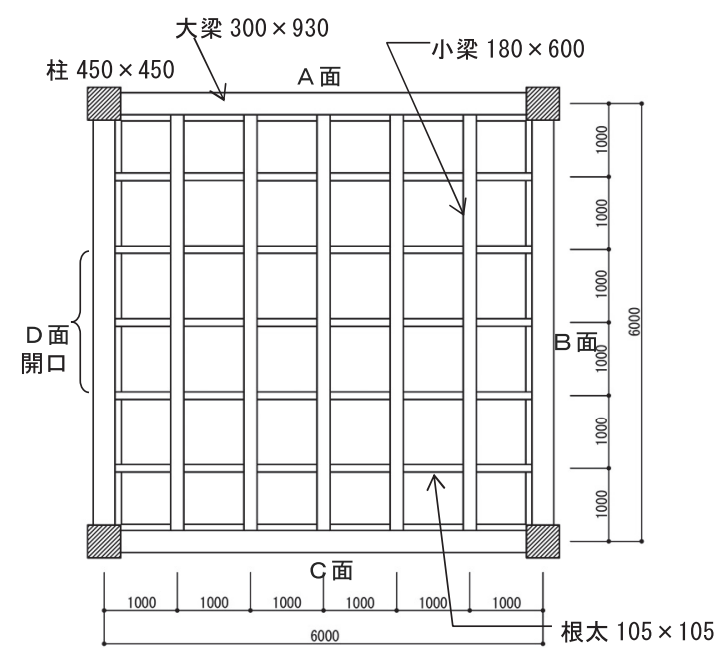

図 2 基本的な平面架構図

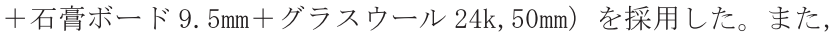
下室の天井高は $2.5 \mathrm{~m}$, 壁構造は石膏ボード $12.5 \mathrm{~mm} \times 2$ 枚: 両面張り である。なお，壁 4 面（A～D 面）のうち 1 面（D 面）には $2 \mathrm{~m} \times 2 \mathrm{~m}$ の開口部（断熱防音サッシ）がある。基本的な平面架構図を図 2 に 示した。

\section{3 実験床の構造}

一般的なコンクリート造では，床スラブ厚を増す（質量・剛性増 加）ことが重量床衝撃音対策の基本とされるが，木造では質量増加 は構造的に限界がある。そこで, 本研究では, 剛性増加に着目した 高剛性構造方式, 振動伝達率低減を意図した防振構造方式とこれら 2 つを組合せた高剛性・防振構造方式の 3 方式の床を検討した。本 報では, これらのうち, 高剛性構造方式による検討結果と防振構造 方式の一部について報告寸る。

高剛性構造方式の床として,「根太床」「重量床」「パネル床(1)」パ ネル床(2)」の 4 種類，防振構造方式は「防振床」の 1 種類とした。 各構造方式床の代表的な断面構成を図 3〜7 (図中の仕様N No.は表 1 参 照）に示す。

図 3 の「根太床」は，木質系床構造の基本となる合板重衫張り床 構造であり，5 本の小梁（@1000）間に根太（@1000）を配した在 来工法床である。床仕様は, 構造用合板 $24 \mathrm{~mm}+$ アスファルト系遮音 シート $4 \mathrm{~mm}+$ 合板 $12 \mathrm{~mm}$ とした。

図 4 の「重量床」は，2 本の小梁（@2000）上に 100mm 厚の穴あ き PC 版（1000×5700）6 枚を敷設したハイブリッド構造である。PC 版のジョイント部にはモルタルを注入し，石膏系セルフレベリング 材 $20 \mathrm{~mm}$ 仕上げとした。

図 5 に示した「パネル床(1)」は, LVL 材（t=48mm）を用いたボッ クス型床パネル 5 枚 $(1200 \times 5500 \times 280 \times 3$ 枚, $1045 \times 5500 \times 280 \times 2$ 枚）を大梁の上端に合わせて落とし込む形で施工した。この場合小 梁は架けていない。なお,パネル同士の接合方法はビス接合とした。

図 6 に示した「パネル床(2)」は，角材 $(105 \times 150 @ 250)$ の上下両 面に合板 $24 \mathrm{~mm}$ を接着し，高剛性化を狙ったパネル床（2000×5700 ×198）であり，5本の小梁（@1000）と根太（@1000）上に敷設し たものである。なお，部材接合には一般性を重視し木工用ボンドを 用いた。また，パネル同士の接合方法はビス接合とした。

図 7 に示した「防振床」は, 5 本の小梁（@1000）と根太（@1000) 上に $70 \mathrm{~mm}$ 厚の PS 版 $(2000 \times 3000) 6$ 枚を敷設したハイブリッド構 造であり，発泡ポリウレタン緩衝材 $(100 \times 100, \mathrm{t} 12.5$, バネ定数： $\left.2.5 \times 10^{7} \mathrm{~N} / \mathrm{m} \cdot \mathrm{m}^{2}\right)$ による防振支持とした。なお，PS版同士の

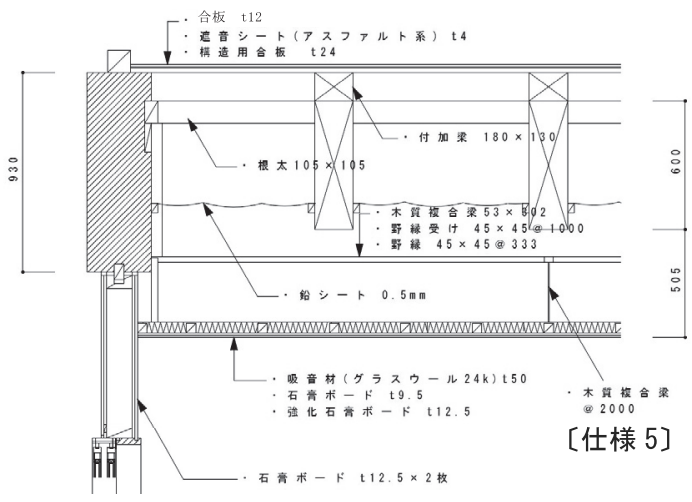

図 3 高剛性構造床（根太床：在来工法床） 


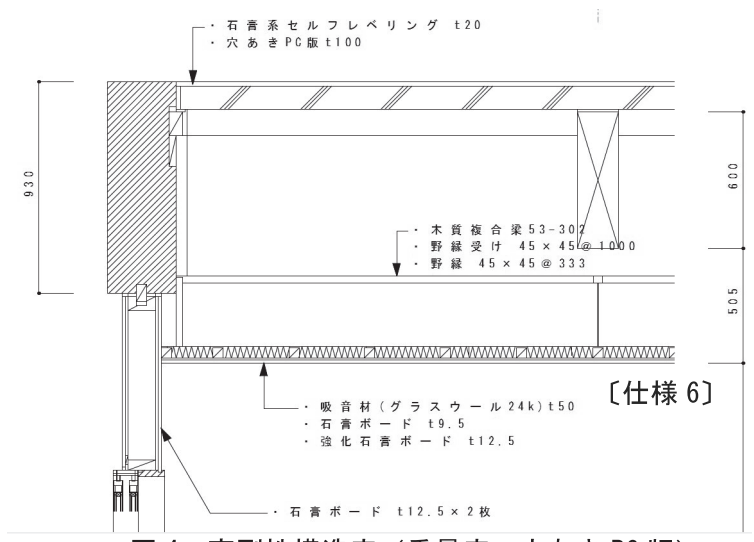

図 4 高剛性構造床（重量床：穴あき PC 版）

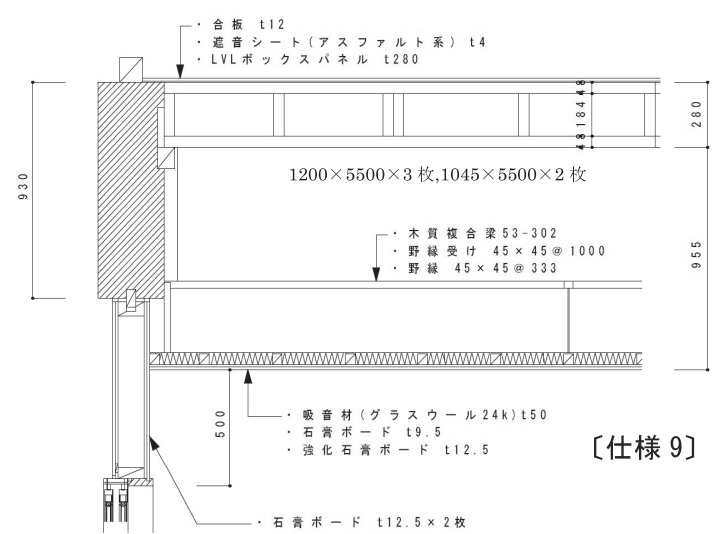

図 5 高剛性構造床（パネル床(1)：LVL ボックス床）

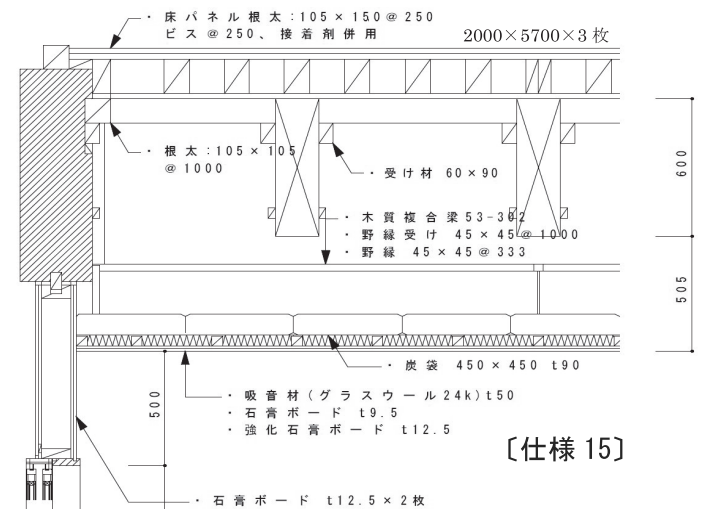

図 6 高剛性構造床（パネル床(2)：高剛性パネル床）

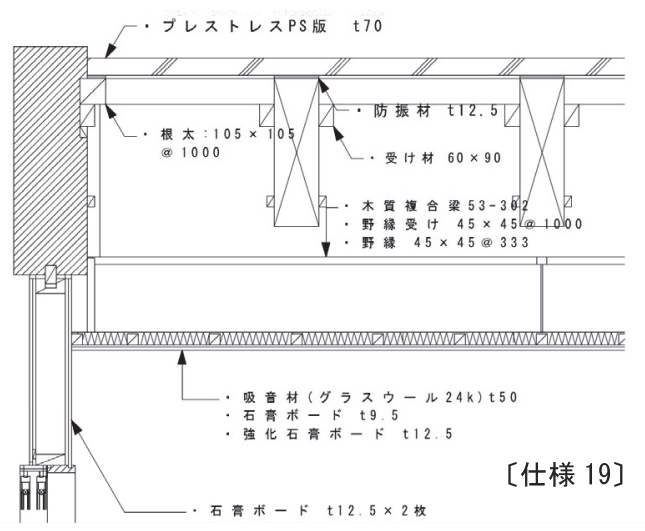

図 7 防振構造床（防振床：PS 版 $70 \mathrm{~mm}$ )
接続は金属プレート $(50 \times 100 t 5 @ 1000)$ によりパネル上面のみボル トで緊結した。

\section{3. 高剛性構造方式}

\section{1 実験仕様及び実験方法}

高剛性構造床の実験仕様リストを表 1 に示した。根太床（図 3) は天井を標準仕様とした仕様 2（基本仕様(1)）を含み，天井構造を 変化させた仕様 1～5 とした。重量床は仕様 6 （図 4）の 1 仕様のみ とし，パネル床(1)（図 5）は天井を標準仕様とした仕様 9（基本仕様 (3)）を含み, 天井構造を変化させた仕様 7〜12 とした。また，パネ ル床(2)（図 6）は天井を標準仕様とした仕様 13（基本仕様(4)）を含 み, 天井構造の違いや二重床の有無を含む仕様 13〜16 とした。

天井構造は，基本仕様の他に，「天井なし」「鉛シート $0.5 \mathrm{~mm}$ （小 梁間に角材と小梁で挟み施工）(図 3 参照)」「基本仕様 + 強化石膏ボ ード $15 \mathrm{~mm}$ 「基本仕様十強化石膏ボード $15 \mathrm{~mm}+$ 鉛シート $0.5 \mathrm{~mm}$ 「石 膏ボード $9.5 \mathrm{~mm}+$ グラスウール $24 \mathrm{k}, 50 \mathrm{~mm}$ およよ゙「基本仕様十炭袋 $36 \mathrm{~m}^{2}$ 敷設」（仕様 15）の 7 種類とし，さらに「基本仕様十強化石膏 ボード $15 \mathrm{~mm}$ の強化石膏ボート $15 \mathrm{~mm}$ については, $1000 \times 1000 \mathrm{~mm}$ 寸法の強化石膏ボードを市松模様に設置した仕様 11 と, $1000 \times 2000$ $\mathrm{mm}$ の寸法の強化石膏ボードを短冊状に平行配置した仕様 12 も設定 した。

仕様 15 の炭袋は, 天井裏に敷設することにより質量付加と石膏ボ 一ドの制振，天井裏空間の吸音性の増加を目的としたものである。 この炭袋（11. $2 \mathrm{~kg} / \mathrm{m}^{2}$, t90） は市販の天井用調湿木炭6）であり，杉・ 松・ヒノキを原料とした木材を特殊な破砕機によりチップ化し $800^{\circ} \mathrm{C}$ で 1 時間加熱処理して炭化させ, 縦横 $45 \mathrm{~cm}$ の不織布袋中に 15 リットル詰めたものである。

床の上部構造として付加した仕様 16 の乾式二重床 $(1820 \times 1830)$

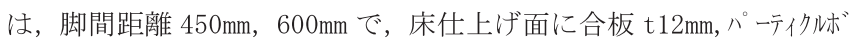
ード $\mathrm{t} 20 \mathrm{~mm}$ 仕上げ高さを $120 \mathrm{~mm}$ (脚高さ $88 \mathrm{~mm}$ ) ゴム硬度 $50^{\circ}$ とした。 なお，この乾式二重床構造に単振動系を仮定した場合の計算上の一 次固有振動数は $63 \mathrm{~Hz}$ 帯域の床躯体構造への振動伝達率を低下させ
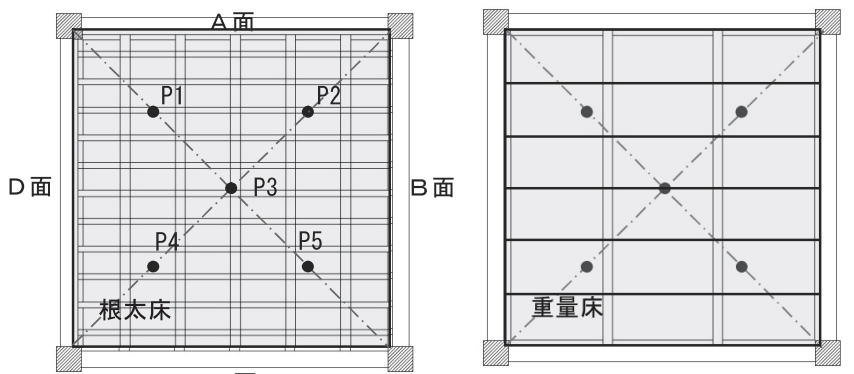

C 面
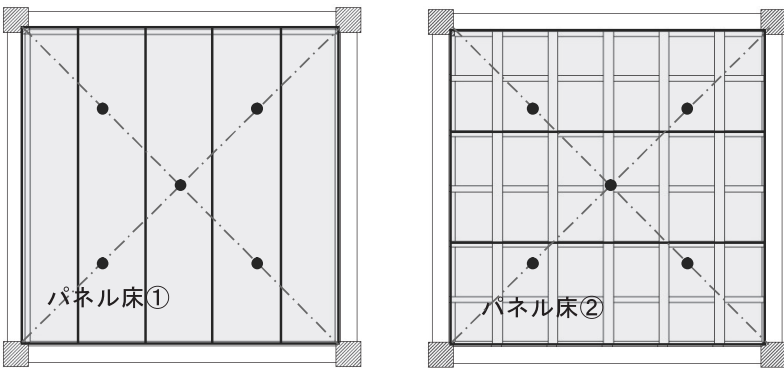

図 8 高剛性パネル床等の配置と加振点 
表 1 実験仕様リストおよび床衝撃音測定結果

\begin{tabular}{|c|c|c|c|c|c|c|c|c|}
\hline \multirow{2}{*}{$\begin{array}{c}\text { 仕様 } \\
\text { №. }\end{array}$} & \multirow{2}{*}{ 構造種別 } & \multicolumn{3}{|c|}{ 床構造 } & \multirow{2}{*}{ 天井構造 } & \multirow{2}{*}{ 重量床 } & \multirow{2}{*}{$\begin{array}{c}\text { 決定周波数 } \\
(\mathrm{Hz})\end{array}$} & \multirow{2}{*}{ 備考 } \\
\hline & & & 下部構造 & 上部構造 & & & & \\
\hline 1 & 根太床 & $\begin{array}{l}\text { 小梁@1000, } 5 \text { 本 } \\
\text { 甲乙梁@500 }\end{array}$ & $\begin{array}{l}\text { 構造用合板 } 24+\text { ×スフアルト系 } \\
\text { 遮音シーート4+下地合板12 }\end{array}$ & - & - & $\mathrm{L}-75$ & 250 & \\
\hline 2 & 同上 & 同上 & 同上 & - & 強化PB12.5 + PB9.5+GW50(24k) & $\llcorner-65$ & 63 & 基本仕様(1) \\
\hline 3 & 同上 & 同上 & 同上 & - & $\begin{array}{l}\text { 強化PB } 15+\text { 強化PB12.5+PB9.5+ } \\
\text { GW50(24k) }\end{array}$ & L-60 & 63 & \\
\hline 4 & 同上 & 同上 & 同上 & - & 鉛シート 0.5 & $L-60$ & 63 & \\
\hline 5 & 同上 & 同上 & 同上 & - & $\begin{array}{l}\text { 強化PB12.5+PB9.5+GW50(24k)+ } \\
\text { 鉛シート0.5 }\end{array}$ & L-60 & 63 & 図3 \\
\hline 6 & 重量床 & 小梁@2000, 2本 & $\begin{array}{l}\text { 穴あきPC版 } 100+ \\
\text { 石膏系セルフレベリング20 }\end{array}$ & - & 強化PB12.5 + PB9.5+ GW50(24k) & $\mathrm{L}-65$ & 63 & 基本仕様(2)，図4 \\
\hline 7 & パネル床(1) & - & $\begin{array}{l}\text { LVLボックス床パネル280+アスフアルト系 } \\
\text { 遮音シート4+下地合板 } 12\end{array}$ & - & - & $\mathrm{L}-75$ & 63 & \\
\hline 8 & 同上 & - & 同上 & - & PB9.5+GW50(24k) & $\llcorner-70$ & 63 & \\
\hline 9 & 同上 & - & 同上 & - & 強化PB12.5+PB9.5+GW50(24k) & L-65 & 63 & 基本仕様(3)，図5 \\
\hline 10 & 同上 & - & 同上 & - & $\begin{array}{l}\text { 強化PB15+強化PB12.5 +PB9.5+ } \\
\text { GW50(24k) }\end{array}$ & $\llcorner-65$ & 63 & \\
\hline 11 & 同上 & - & 同上 & - & $\begin{array}{l}\text { 強化PB15(市松)+強化PB12.5+ } \\
\text { PB9.5+GW0(24k) }\end{array}$ & L-65 & 63 & \\
\hline 12 & 同上 & - & 同上 & - & $\begin{array}{l}\text { 強化PB15(短冊) + 強化PB12.5+ } \\
\text { PB9.5+G50(24k) }\end{array}$ & $\llcorner-65$ & 63 & \\
\hline 13 & パネル床(2) & $\begin{array}{l}\text { 小梁@1000,5本 } \\
\text { 甲乙梁@1000 }\end{array}$ & $\begin{array}{l}\text { 木質パネル198(構造用合板 } 24+\text { 根太 } \\
105 \times 150 @ 250+\text { 構造用合板合板 } 24)\end{array}$ & - & 強化PB12.5+PB9.5+GW50(24k) & $\mathrm{L}-65$ & 63 & 基本仕様(4) \\
\hline 14 & 同上 & 同上 & 同上 & - & $\begin{array}{l}\text { 強化PB12.5+PB9. } 5+\text { GW50 }(24 k)+ \\
\text { 鉛シート0.5 }\end{array}$ & $\mathrm{L}-60$ & 63 & \\
\hline 15 & 同上 & 同上 & 同上 & - & $\begin{array}{l}\text { 強化PB12.5+PB9.5+GW50(24k)+ } \\
\text { 炭袋 } 36 \mathrm{~m}^{2}\end{array}$ & $L-60$ & 63 & 図6 \\
\hline 17 & 防振床 & $\begin{array}{l}\text { 小梁@1000,5本 } \\
\text { 甲乙梁@1000 }\end{array}$ & $\begin{array}{l}\text { PS版70 } \\
\text { 直置き }\end{array}$ & - & 強化PB12.5+PB9.5+GW50(24k) & $\mathrm{L}-60$ & 63 & \\
\hline 18 & 同上 & 同上 & $\begin{array}{l}P S \text { 版70 } \\
\text { 緩衝材ゴム支持 }\left(\mathrm{f}_{0}=15 \mathrm{~Hz}\right)\end{array}$ & - & 同上 & $\mathrm{L}-60$ & 63 & 図7 \\
\hline 19 & 同上 & 同上 & $\begin{array}{l}\text { PS版70 } \\
\text { ポリウレタン緩衝材支持 }\left(\mathrm{f}_{0}=15 \mathrm{~Hz}\right)\end{array}$ & - & 同上 & L-55 & 63 & \\
\hline
\end{tabular}

注) 寸法数字の単位：mm，乾式二重床：端部開放、「一」：無し、PB：石高ボード，GW：グラスウール，炭袋：面密度 $11.2 \mathrm{~kg} / \mathrm{m}^{2}$

るため脚の下部に設置したゴムのばね定数で調整し、25Hz に設定し た。また，乾式二重床の周辺部は開放とした。

重量床衝撃音レベルの測定方法は JIS A 1418-2 に準拠し, 加振源 にはバングマシンを用いた。

図 8 に床の配置（太線枠）と床衝撃音測定の加振点位置を示す。 実験項目は重量床衝撃音, 駆動点インピーダンス, 下室各部位への 伝達振動とした。重量床衝撃音の加振点は床の中央を含む対角線上 の $\mathrm{P} 1 \sim \mathrm{P} 5$ の 5 点とし, 下階の受音点も加振点直下の 5 点とした。な お, 受音点高さは下階の床上 $700 \sim 1500 \mathrm{~mm}$ の間で $200 \mathrm{~mm}$ ピッチに変 化させた。駆動点インピーダンス測定は床中央点 P3 のみで行い, 加 振源にはインパルスハンマー（衝撃周波数 $160 \mathrm{~Hz}$ : 実測值) を用い た。各床構造仕様の基本性能である駆動点インピーダンス測定結果 を図 9 に示した。また, 振動速度レベルの測定は, バングマシンで 床中央 P3 の 1 点を加振し, 床面及び下室の天井面, 壁面の各面に 9 点の異なった測定点を設け振動速度応答を測定した。

\section{2 測定結果}

(1) 根太床

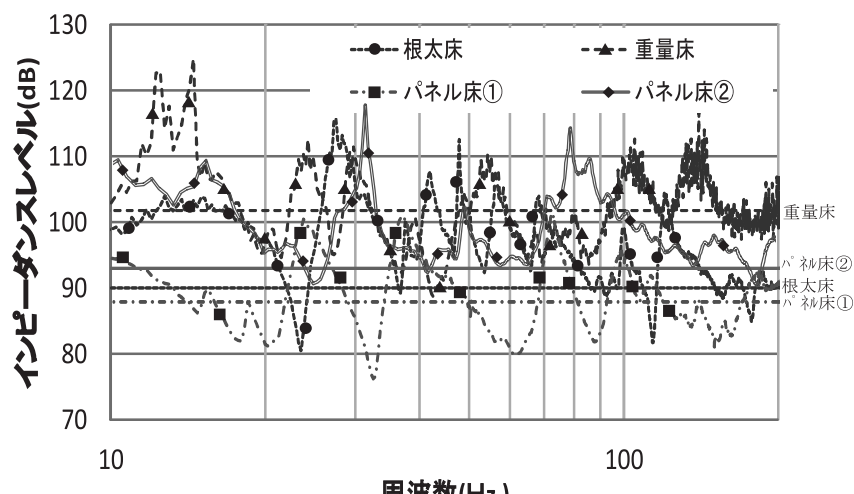

周波数 $(\mathrm{Hz})$

図 9 インピーダンス測定結果

図 9 をみると衝撃時間内応答インピーダンス 7) は $90 \mathrm{~dB}$ 程度を示 し，かなり低く，図 3 の断面仕様からみると面材の効果というより も, 構造的に不連続となる「小梁+付加梁」の性能とみることがで きる。

全時間応答インピーダンス特性から一次固有振動数は $23 \mathrm{~Hz}$ とな 

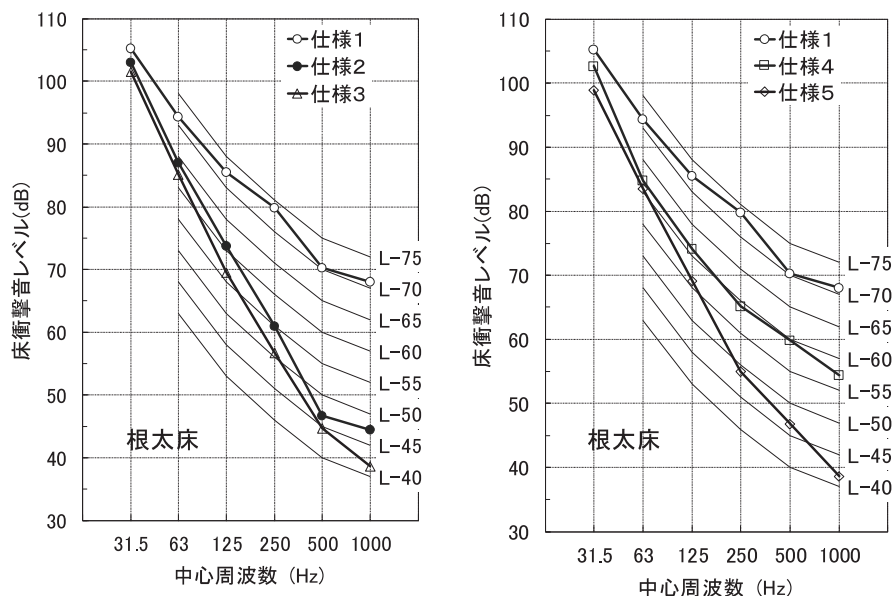

図 10 床衝撃音測定結果

り，小梁の影響が大きいと考えられる。そこで，小梁単体の性能を 別途求めてみたところ, $98 \mathrm{~dB}$ 程度が得られ, 式 (1) より小梁単体 の衝撃周波数におけるインピーダンス $(\mathrm{Z})$ を算出し ${ }^{8)}$, インピー ダンスレベル（=201ogZ: $\mathrm{dB}$ ref. $1 \mathrm{~kg} / \mathrm{s} ）$ を求めてみると, $98.3 \mathrm{~dB}$ と算出されほほぼ同程度であった。

$$
\mathrm{Z}=2 \mathrm{mC}
$$

ただし， $\mathrm{m}$ 単位面積当りの質量 $(\mathrm{kg} / \mathrm{m}), \mathrm{C}_{\mathrm{b}}$ :曲げ波速度 $(\mathrm{m} / \mathrm{s})$ なお, 曲げ波速度 $\mathrm{C}_{\mathrm{b}}$ は式 (2), 縦波速度 $\mathrm{C}_{1}$ は式（3）より求めた。

$$
\begin{aligned}
& C_{b}=\sqrt{\frac{\pi \cdot C_{1} \cdot h \cdot f}{\sqrt{3}}} \\
& C_{1}=\sqrt{\frac{E}{\rho}}
\end{aligned}
$$

ただし，f=中心周波数 $(\mathrm{Hz}), \mathrm{h}=$ 等価厚 $(\mathrm{m}), \mathrm{E}=$ ヤング係数 $\left(\mathrm{N} / \mathrm{m}^{2}\right)$ $\rho=$ 密度 $\left(\mathrm{kg} / \mathrm{m}^{3}\right)$

しかしながら, 根太床の合板施工後に床上で測定した床中央点は, 梁単体の実測值を $8 \mathrm{~dB}$ 程度下回った。これは部材同士をビス接合し たために床上部構造が梁とは一体化せずに応答した付加梁, 上面合 板や根太の局所振動の影響や, 遮音シートのば䄈の影響が考えられ る。これらの測定結果から, 今回の床構造のように断面せいが大き なものでも, 複合床の場合は, 衝撃時間内応答インピーダンスレベ ルが $100 \mathrm{~dB}$ 以上の性能を達 成するのは難しいと言える。

図 10 に根太床(合板重㸚 張り床) の重量床衝撃音測 定結果を示す。天井構造を 石膏ボード 2 枚張りのみと した仕様 2 は, L-65 の性能 であり，共振的増幅の影響 もなく衝撃力特性に近似し た素直な周波数特性を示し ている。天井の標準仕様に 強化石膏ボード $15 \mathrm{~mm}$ を付 加した仕様 3 は, 仕様 2 に
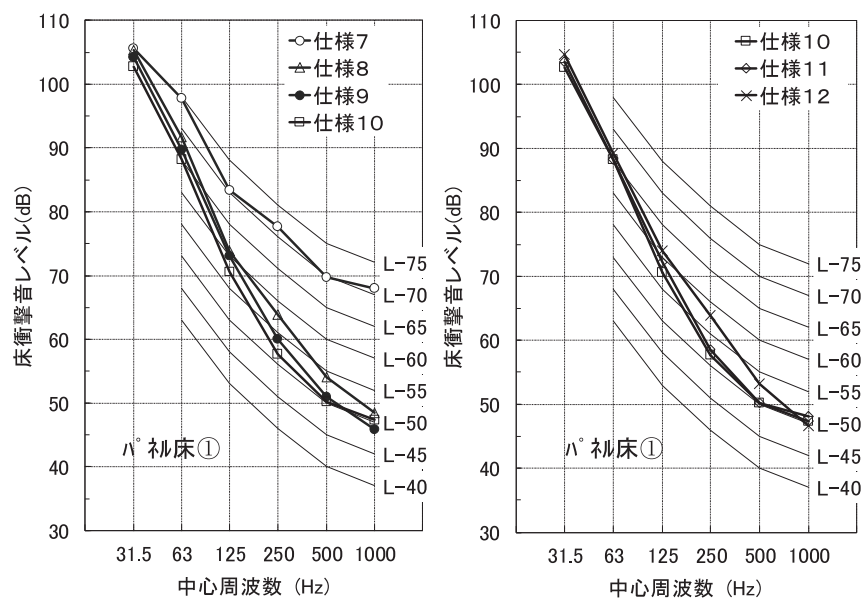

図 12 床衝撃音測定結果

比べ 63 500Hz 帯域で 2 4dB の低減効果が見られ, 天井の断面仕様 による透過損失の計算值の差（拡散入射時 $3.5 \mathrm{~dB}$ ） と良く対応して (る ${ }^{9)}$ 。

天井の無い仕様 1 の測定結果は L-75（決定周波数は 250Hz）であ り, 仕様 2 との比較から, 天井（標準仕様）の効果は L 值で 2 ラン ク，63Hz 帯域では $7 \mathrm{~dB}$ であった。したがって, 独立型遮音天井とし た本仕様は天井が有効に作用しているものと考えられる。天井がな く小梁間に施工した鉛シート $0.5 \mathrm{~mm}$ のみの仕様 4 を天井のない仕様 1 と比較すると, 鉛シートの効果は $63 \mathrm{~Hz}$ 帯域で $10 \mathrm{~dB}$ を示し, 垂直 入射時の質量則による值（9dB）に近似する值が得られた。

また, 天井の標準仕様に鉛シート $0.5 \mathrm{~mm}$ を施工した仕様 5 （図 3 参照）を鉛シート $0.5 \mathrm{~mm}$ のみの仕様 4 と比較すると, 鉛シートのた め板振動に共振等の付加の影響はないが，天井質量と空気層間の共 振の付加影響のためか, $63 \mathrm{~Hz}$ 帯域での効果は $1 \mathrm{~dB}$ となっている。し かし, 高域の 125〜 500Hz 帯域では 5〜13dB の効果を示しており, 遮 音天井内に鉛シートによる遮音層を設ける効果が確認できる。

\section{(2) 重量床}

重量床は穴あきPC版を用いたハイブリッド構造である。図 9 の床 中央の梁間となる点の衝撃時間内応答インピーダンスを見ると 102 $\mathrm{dB}$ となり, 計算值 $104 \mathrm{~dB}$ と比較すると対応が良い。一次固有振動数 は, $19 \mathrm{~Hz}$ 程度となった。これは小梁の剛性と PC版の質量による振 動系の影響が大きいと考えられる。

全時間応答インピーダンス特性は小梁や $1000 \times 5700$ の PC 版，小
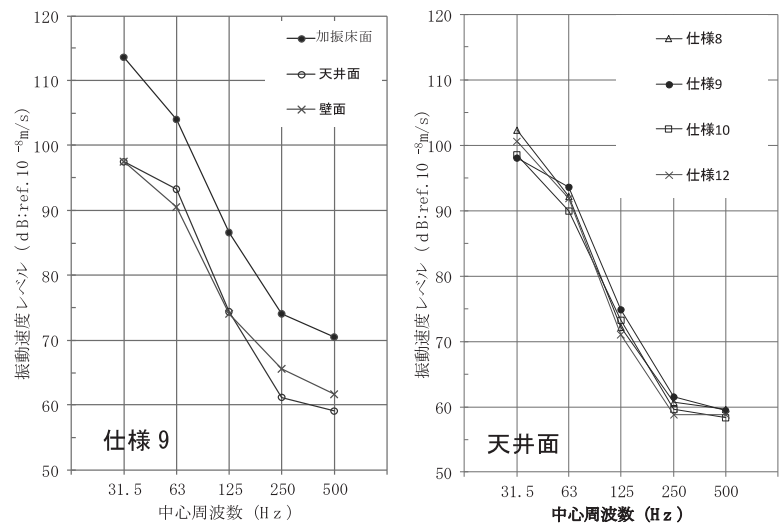

図 13 パネル床(1)における各振動速度レベル結果 
梁の補剛効果など局部振動が付加されるために, 多くの共振現象を 生じているが, 全体的には, PC 版が連続しているために周波数特性 としては, ほぼ平坦な形を示している。

図 11 に重量床の重量床衝撃音測定結果を示す。これより, $63 \mathrm{~Hz}$ 帯域で共振による若干の増幅が認められるが，小梁を 2 本設置（@ $2000 \mathrm{~mm}$ ）した効果も影響しているものと考えられる。図 9 を見ると 根太床との衝撃時間内応答インピーダンスには $10 \mathrm{~dB}$ の差が生じて いる。しかし, 帯域別インピーダンスを算出してみると, 重量床衝 撃音の決定周波数である, $63 \mathrm{~Hz}$ 帯域では重量床 $95 \mathrm{~dB}$, 根太床 $96 \mathrm{~dB}$ と同程度の值であり, 根太床の基本仕様 2 と同ランクの $\mathrm{L}-65$ の性能 という結果となった。

\section{(3) パネル床(1)}

パネル床(1) L LVL 材を用いた厚さ $280 \mathrm{~mm}$ のボックス型パネル床で ある。架構方式として, 構造的に $6 \mathrm{~m}$ スパンは可能であるため, 小 梁は架けていない。図 12 にパネル床(1)の重量床衝撃音測定結果を示 す。天井の無い仕様 7 の測定結果は, $63 \mathrm{~Hz}$ 帯域での増幅が多少認め られ L-75 であった。インピーダンスの值は断面せいが大きいことか ら部材同士の一体化が実現されていれば $107 \mathrm{~dB}$ と $100 \mathrm{~dB}$ を上回る值 を示すはずであるが, 実測值は $88 \mathrm{~dB}$ を示し, 各部材の曲げ剛性を加 算して得られた計算值の $88 \mathrm{~dB}$ と対応している。天井が標準仕様であ る仕様 9 (L-65) との比較から, 標準仕様の天井（石膏ボード 2 層 $+\mathrm{GW})$ による効果は $\mathrm{L}$ 值の性能差で 2 ランク（63Hz 帯域で $8 \mathrm{~dB} ）$ と なり, 仕様 2 と同様に独立型天井の効果が大きいことが判る。天井 の石膏ボードが 1 層の仕様 8 と 3 層の仕様 10 の性能差は 1 ランク （L-70 と L-65）であり，63〜 500Hz 帯域で 3〜 6dB の効果が見られ 質量付加による遮音性能の向上とみることができる。強化石膏ボー ド $15 \mathrm{~mm}$ の増張り工法（市松：仕様 11, 短冊：仕様 12）による差は 125 500Hz 帯域で認められ野縁間共振の制御には市松張りによる 板振動制御効果があることがわかる。しかし，L值では $63 \mathrm{~Hz}$ 帯域が 決定周波数となり，この領域における板振動制御効果は小さく，共 にL-65 であった。図 13 に中央加振時における各面の振動速度忘答 の結果を示す。加振した 2 階床面の振動速度レベルの值が大きいが, 衝撃時間内応答インピーダンスが低く, 基本的に低剛性, 低質量が 原因であり,パネル同士の接合が弱いことも理由として挙げられる。 しかし, 天井面の振動速度レベルは低減していることから, 独立型 天井は必須であると言える。また, 仕様 8～12 の天井面の振動速度
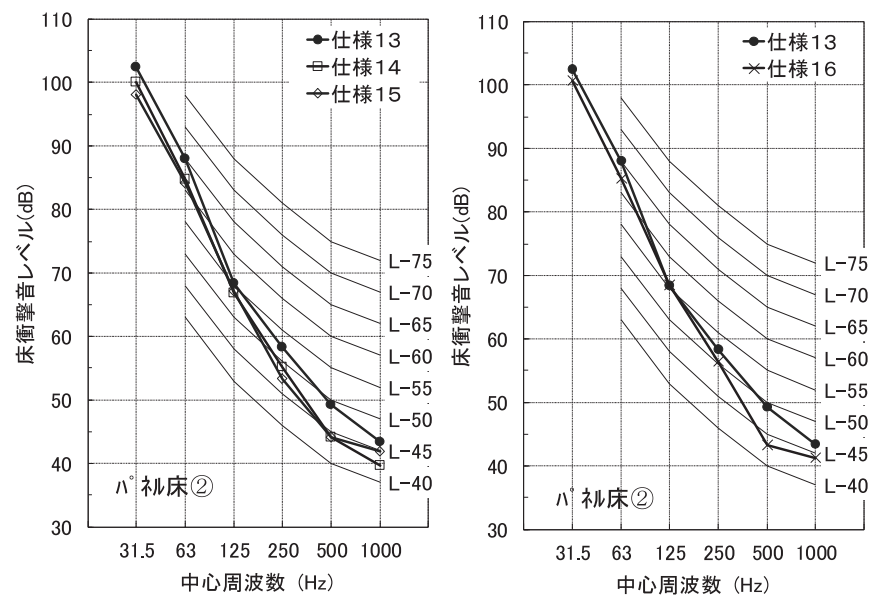

図 14 床衝撃音測定結果
レベルをみると同程度の結果となっている。天井仕様の変化により， 図 12 と同様, 振動応答の面からも効果は対応していると言えるが, パネル面からの放射音を低下させる，すなわちパネルの剛性，質量 をある程度増加させないと更なる性能向上は難しいことがわかる。

\section{(4) パネル床(2)}

パネル床(2)は根太（105×150@250）の上下両面に合板 $24 \mathrm{~mm}$ を接 着し，高剛性化を意図し，パネル床(1)の性能を上回ると想定してい たパネル床である。図 14 にパネル床(2)の重量床衝撃音測定結果を示 す。これより, 天井構造が標準仕様である基本仕様 13 は想定を下回 る L-65 の性能であった。既報 ${ }^{10)}$ では, パネル床(2)の駆動点インピ ーダンスおよび伝達インピーダンスの測定結果を報告したが，その 結果から，衝撃時間内応答インピーダンスの実測值が一体化した高 剛性パネルとしての計算值と乘離していることと, 伝達インピーダ ンス分布 $(63 \mathrm{~Hz})$ から，板全体が 3 枚のパネルで明確に区分されて いる様子が確認された。図 9 をみると, 衝撃時間内応答インピーダ ンス值は $93 \mathrm{~dB}$ であるが, 小梁上のパネル(2)のみを対象として算出し てみると $92 \mathrm{~dB}$ となり, 実測值とほぼ一致する結果となる。したがっ て, パネル構造床の部材接合方法と, パネル同士の接合方法につい てはさらなる検討が必要と考える。

標準仕様の天井に鉛シート $2 \mathrm{~mm}$ を付加した仕様 14 は，基本仕様 13 に比心゙ $63 \mathrm{~Hz}$ 帯域で $3 \mathrm{~dB}$ の低減効果が見られた。また，標準仕様 の天井に炭袋を $30 \mathrm{~m}^{2}$ 敷設した仕様 15 は，基本仕様 13 に比べ $63 \mathrm{~Hz}$ 帯域で $4 \mathrm{~dB}$ の低減効果が見られた。これは，炭袋敷設による面密度 増加や制振効果および天井内吸音力増加による効果と考えられ有効 な対策方法であると言える ${ }^{6)}$

乾式二重床を付加した仕様 16 は, 仕様 13 に比べ $63 \mathrm{~Hz}$ 帯域で $3 \mathrm{~dB}$ の低減効果が見られ，二重床設置による床面への加振力が抑制され たものと考えられる。なお,この二重床は $3.3 \mathrm{~m}^{2}$ の大さで施工し, 床加振時に各加振点に移動してバングマシンにより加振した。

以上のように，仕様 $14 \sim$ 仕様 16 による低減効果はともに $3 \sim 4 \mathrm{~dB}$ 程度得られ，L 值は基本仕様 13 から 1 ランク向上（L-60）した。

\section{4 防振構造方式}

防振構造床には，コンクリートの特徴を生かしながら軽量化を図 るためのプレストレス版（PS 版 $70 \mathrm{~mm} 2 \mathrm{~m} \times 3 \mathrm{~m}$ ) を導入した。

\section{1 実験仕様}

表 1 の仕様 17〜19 はPS 版の支持方式に着目したもので，天井は いずれも標準仕様（PB12.5+9.5mm）である。仕様 17 は PS 版を梁架 構上に直置きし, 仕様 18 は緩衝材として防振ゴム厚さ（100×100, t $25 @ 1000 \mathrm{~mm}$ ，ゴム硬度 $60^{\circ}$ ）を用いた。また，仕様 19 は発泡ポ

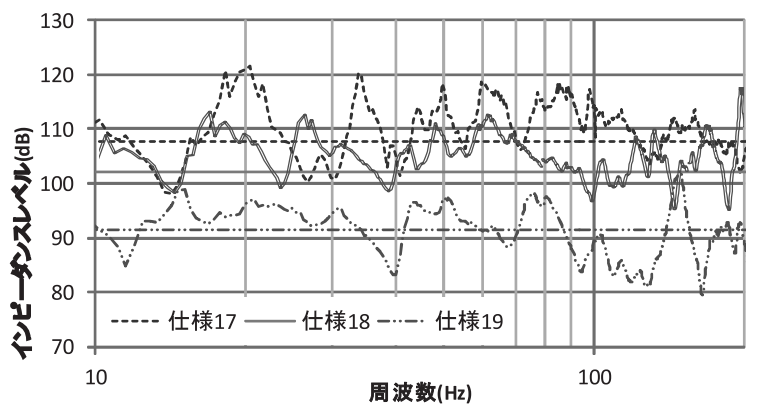

図 15 防振床の佗 
リウレタン緩衝材 $(100 \times 100$, t $12.5 @ 1000$ mm $)$ により防振支持し たものである。なお，仕様 $18 ， 19$ の防振系のバネ定数は $2.5 \times$ $10^{7} \mathrm{~N} / \mathrm{m} \cdot \mathrm{m}^{2}$ であり, 計算上の一次固有振動数は共に $15 \mathrm{~Hz}$ に設定した。

\section{2 測定結果}

図 15 に床中央点の駆動点インピーダンスの結果を示す。仕様 17 , 19 のインピーダンス結果を比較すると仕様 17 の結果は全体的に周 辺支持材や小梁が補剛効果として働き，全体的にインピーダンスは 高い值を示しており，床面の性能としては良く, $100 \mathrm{~Hz}$ 付近までは 均質版のインピーダンス特性を示している。しかし，100Hz 付近を 超えると, 木床構造の質量一バ玅が影響し, $-6 \mathrm{~dB} /$ oct. の傾向を示 している。一次固有振動数は $15 \mathrm{~Hz}$ を示しており, PS 版の質量 1.05 $\mathrm{t}$ と小梁及び根太の曲げバ祀仮定すると $11 \mathrm{~Hz}$ と計算され, 実測值 と比較的対応している。仕様 19 の結果は, 衝撃インピーダンスが仕 様 17 よりも $15 \mathrm{~dB}$ 低下しており, PS 版は小梁と分離していると考え られる。そこで, 均質なプレストレス PS 版として無限版を想定した 駆動点インピーダンスを計算してみると $94 \mathrm{~dB}$ となり, 実測値とよく 対応している。なお, 予備実験でPS 版を吊り下げた状態でインピー ダンスの測定を行ったが, その測定結果ともよく対応しており, 浮 き床構造が成立していると言える。一次固有振動数は $12 \mathrm{~Hz}$ を示し計 算值の $15 \mathrm{~Hz}$ に比べ若干低下傾向にはあるが，ほぼ対応している。ま た, 一次固有振動数以降は均質版の周波数特性結果を示しており, 高域で共振が強い傾向にはあるが，平坦な特性を示している。

図 16 に重量床衝撃音の測定結果を示す。架構上に直置きした仕様 17 をみると, 共振的増幅も 認められずL-60であった。 仕様 18 は防振ゴム支持で あるが，その効果は $125 \mathrm{~Hz}$ 帯域以上で認められるが, L 值の決定周波数帯域である $63 \mathrm{~Hz}$ の低隇量が小さいた め L-60 の性能に留まって いる。次に, ポリウレタン 緩衝材支持の基本仕様 19 は, 防振効果がほぼ全帯域 に認められ本研究において 最も性能の良い $\mathrm{L}-55$ であ った。

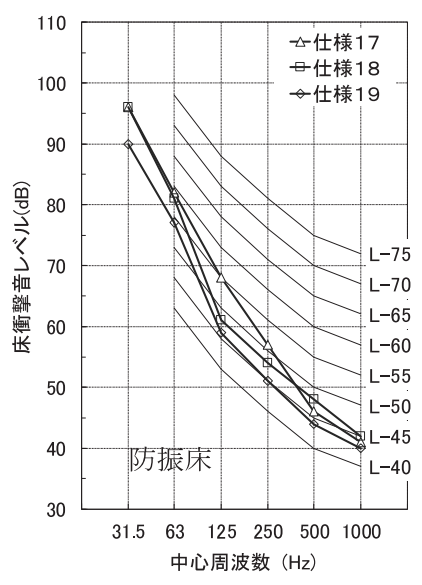

図 16 床衝撃音測定結果

\section{5 まとめ}

床構造に高剛性構造方式を採用することにより,木造でも RC 構造 等を対象にした重量床衝撃音の適用等級 3 級と同等の L-60 の性能を 実際に施工可能な仕様において実現できることが分かった。そして 本研究において更なる対策を目的とした防振構造方式を採用するこ とにより木質構造でも L-55 の達成を可能とした。今後安定した性能 を達成できる仕様一覧をまとめて行くつもりである。

なお本報では従来の床構造仕様の忘用により, L-55 までの性能の 報告としたが、著者らは上部防振系として制振効果及び質量を増加 させた乾式二重床を採用することにより $\mathrm{L}-45$ の性能の確保を確認 している ${ }^{11)}$ 。よって, 次報において引続き報告する予定である。

\section{参考文献}

1）日本建築学会編：建築物の遮音性能基準と設計指針〔第二版〕，技報堂出 版, 1997.12

2）井上勝夫，木村翔，宮崎浩司：木質系床構造の重量床衝撃源に対する床衝 撃音低減方法に関する研究, 日本建築学計画系論文報告集, 第 382 号, pp. 1-9, 1987. 12

3) 笠井祐輔, 村上剛士, 田中学：二重床および二重天井を付加した CLT 床版 の床衝撃音遮断性能, 日本騒音制御工学会秋季研究発表会講演論文集, pp. 171-174, 2015.9

4) 田中学, 平光厚雄他 5 名 : 枠組壁工法による長スパン木造建築の床衝撃音 遮断性能, 日本建築学会大会学術講演梗概集, D-1 分冊, pp. 203-204, 2011.8

5）秋本恭平, 井上勝夫他 2 名：床構造仕様別振動応答による考察 大断面集 成材を用いた純木質構造の重量床衝撃音遮断性能改善方法の研究, 日本騒 音制御工学会研究発表会講演論文集, pp. 167-170,2015.9

6) 中森俊介他 3 名：天井用調湿木炭による床衝撃音低減効果に関する検討, 日本音響学会講演論文集, pp. 1137-1140,2009.3

7）木村翔, 井上勝夫 : 床衝撃音と床スラブの振動特性に関する実験的研究, 日本建築学会論文報告集，第 332 号, pp. 83-93, 1983. 10

8) L. Cremer, M. Heck1, B. A. T. Petersson : Structure-Borne Sound, Springer, 2005

9) 井上勝夫他 6 名 : 実験概要と重量床衝撃音測定結果, 大断面集成材を用い た木造建築物の床衝撃音に関する研究 : その 1 , 日本建築学会大会学術講 演梗概集, D-1 分冊, pp. 319-320, 2012.9

10）依田拓也，井上勝夫他 2 名：大断面集成材を用いた木造建築物の床のイ ンピーダンス特性に関する検討, 日本建築学会大会学術講演梗概集, D-1 分冊, pp. 315-316, 2013.8

11）秋本恭平，井上勝夫他 3 名：純木質構造を対象とした床構造仕様別の重 量床衝撃音遮断性能の検討, 大断面集成材を用いた純木質構造の重量床 衝撃音遮断性能に関する研究: その 1, 日本建築学会大会学術講演梗概 集, D-1 分冊, pp. 147-148, 2015. 


\title{
A STUDY ON THE HEAVY FLOOR IMPACT SOUND INSULATION PERFORMANCE IN A WOODEN LONG-SPAN STRUCTURE BUILDING
}

An experimental study on improvement methods of floor impact sound insulation performance with floor structure specification Part 1

\author{
Kazuki SAKAMOTO*, Katsuo INOUE ${ }^{* *}$ and Kyohei AKIMOTO*** \\ * Research Assoc. of Architecture, College of Science and Technology, Nihon Univ., M. Eng. \\ * Prof., Dept. of Architecture, College of Science and Technology, Nihon Univ., Dr. Eng. \\ *** Former Grad. Student, Graduate Scool of Science and Technology, Nihon Univ.
}

This study was carried out for the purpose of improving the heavy floor impact sound insulation performance in a wooden building. Performs a real-scale experiment of long-span structure wooden construction with a large cross-section laminated lumber, we have proposed a floor cross-section specifications of each heavy floor impact sound insulation performance rank from the result.

This study, supported specifications that can achieve the L-60 with high rigidity system in, which is same performance of heavy floor impact sound insulation performance $3^{\text {rd }}$ rank for RC structure. In addition, to achieve the more improved performances, L-55 can perform by vibration-proof system with wooden structure.

Moreover, to the sound-absorbing ceiling space, increasing the ceiling mass, and to damping the ceiling has been found to be effective. These performance measures to improve, it was found that the floor impact sound insulation performance sufficiently comparable to the concrete can be realized.

In the future, in the high rigidity structure system, we want to advance the research of better adhesion method of the members and the panel integrated construction method. Also, in the vibration-proof structure system, we want to further advance the study of the selection of the buffer material and the setting of natural frequency. Then, conclude the floor structure specification list for achieve stabled better performances. 